\title{
触 New Disease Reports \\ First report of Mungbean yellow mosaic India virus infecting pumpkin in India
}

J. Pandey and N. Verma

Department of Agriculture Science, AKS University, Sherganj, Satna, Madhya Pradesh 485001, India

*E-mail: neerajverma.2008@yahoo.com

Received: 02 Dec 2017. Published: 23 Dec 2017.

Geminiviridae is the second largest family of plant viruses (Varma et al., 2003). These viruses have emerged as devastating pathogens in the tropics and subtropics and cause heavy economic losses. During a survey in 2017 in Madhya Pradesh state, India, greenhouse-cultivated pumpkin (Cucurbita pepo) plants exhibiting leaf symptoms of mosaic and crumpling, typical of begomovirus infection, were observed. Though diseased plants grew to the same size as symptomless plants, there was no flower formation leading to no fruit production, i.e. 100\% yield loss (Fig. 1). Whiteflies were found associated with the plants.

Young diseased leaves were collected to identify the cause of the suspected virus infection. Total DNA was isolated from leaves of asymptomatic and diseased pumpkin plants using a modified CTAB method (Doyle \& Doyle 1987). Isolated nucleic acid was washed firstly using absolute alcohol and then with $70 \%$ alcohol containing $7.5 \mathrm{M}$ ammonium acetate. All centrifugation steps were carried out at 12,000 rpm for two minutes except the final precipitation which was done at $14000 \mathrm{rpm}$. PCR was performed using the begomovirus group-specific primers (Ramesh et al., 2016) to amplify the partial AV1 gene of DNA A in an automated thermocycler (3B BlackBio Biotech India Ltd, Spain).

Amplicons of the expected size (c. $450 \mathrm{bp}$ ) were obtained from total DNA isolated from diseased leaf samples. PCR-amplified products were sequenced in triplicate and submitted to GenBank (Accession No. MF737341). In BLAST analysis the nucleotide identity was 93.6-98.4\% with Mungbean yellow mosaic India virus (MYMIV; JN368437 and
GQ387501, respectively). The deduced amino acid sequence had 93.5-100\% identity with MYMIV (AF314145 and GQ387501, respectively). No amplification was observed with total DNA from asymptomatic pumpkin plants, suggesting MYMIV was associated with the mosaic and crumpling symptoms. The partially amplified DNA sequence was found to belong the AV1 gene of DNA-A of MYMIV.

Pumpkin is generally propagated in India either in the greenhouse or as an open field crop during the rainy season. India is the second largest producing country of pumpkin in the world after China. This is the first definitive report of MYMIV infection on pumpkin from India and the pathogen may cause severe disease outbreaks in India in the future.

\section{References}

Doyle JJ, Doyle JL, 1987. A rapid DNA isolation procedure for small quantities of fresh leaf tissue. Phytochemical Bulletin 19, 11-15.

Ramesh SV, Chouhan BS, Gupta GK, Ramteke R, Chand S, Husain SM, 2016. Molecular diversity analysis of coat protein gene encoded by legume begomoviruses and PCR assay to detect yellow mosaic viruses infecting soybean in India. British Biotechnology Journal 12, 1-10. http://dx.doi.org/10.9734/BBJ/2016/24362

Varma A, Malathi VG, 2003. Emerging geminivirus problems: a serious threat to crop production. Annals of Applied Biology 142, 145-164. http://dx.doi.org/10.1111/j.1744-7348.2003.tb00240.x

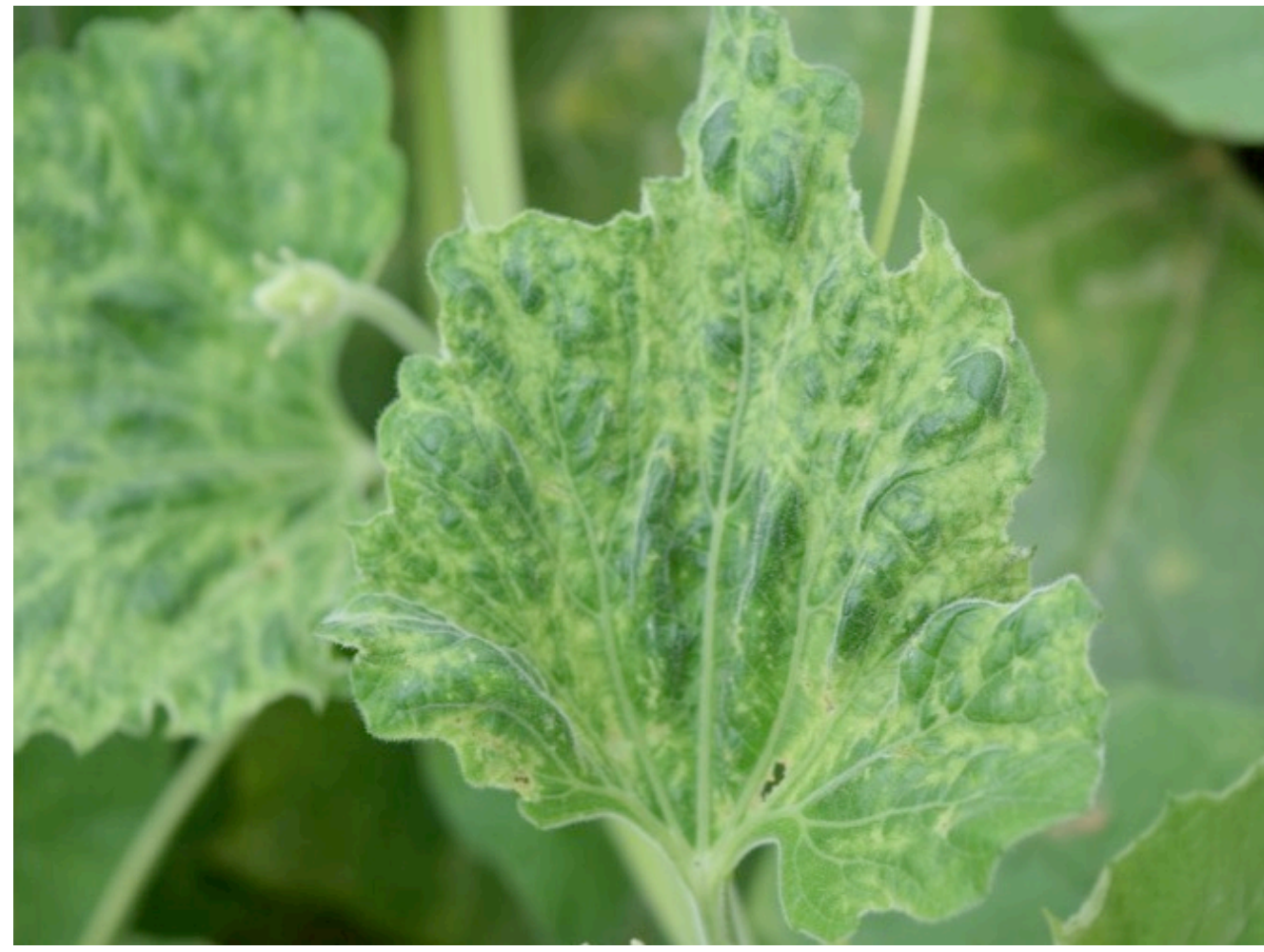

Figure 1

To cite this report: Pandey J, Verma N, 2017. First report of Mungbean yellow mosaic India virus infecting pumpkin in India. New Disease Reports 36, 23. http://dx.doi.org/10.5197/j.2044-0588.2017.036.023 